\title{
Notes on the Diatomaceae of Ahmedabad and Its Environs
}

\author{
by \\ H. P. GandhI \\ Bahauddin College, Junagadh, INDIA \\ (with 1 plate) \\ SYNOPSIS \\ In this note the Diatoms from the Gujarat College compound are \\ systematically described and some notes or remarks are given on \\ their occurrence, ecology and distribution in the region of Ahmedabad.
}

\section{INTRODUCTION}

With the exception of two small notes by the author $(1959,1960)$ there exist no other accounts of the Diatomflora of Ahmedabad region. In order to further add to the knowledge of this flora, the present paper is intended.

While collecting the diatom material from the region of Ahmedabad it was the upper most idea with the author that localities or habitats be classified or categorised and the diatom communities be investigated separately of such bodies of water. Accordingly, the plan was adopted and the body or bodies of water were studied separately under the following heads: 1) Road-side and village ponds, small tanks or large pools much disturbed by biotic agencies, therefore, amply polluted; 2) Garden reservoirs: a. with continuously disturbed water, $b$. long standing polluted disturbed water and $c$. undisturbed water for a long time with aquatic Angiosperms; 3) wet soils under garden taps along with ephemeral shallow puddles formed during the rains; 4) large permanent bodies of water e.g. large tanks, zhils or lakes subject to full force of climatal, edaphic and biotic factors; 5) road-side pools, puddles and ditches more or less secluded or unfrequented by many biotic agencies but subject to climatal and 
edaphic factors; and lastly 6. the pools and slowly flowing watercourses in the river bed. These were all the possible wet situations available in the region of Ahmedabad. Further, it was thought that the collections be made at suitable regular intervals for a year, two or more where- and whatever was possible and the floristic element be examined more carefully and separately from type or set of habitats. Again, the samples of water be taken at different times and chemically analysed and findings be correlated with the occurrence of different species of diatoms. However, in this direction little could be done due to several factors the chief among them being, vicious bosses of the departments, sparse facility characteristically available at several Govt. colleges, indifferent Govt. administration and attitude and the finance.

Despite of manifold difficulties, the author collected a large number of algal samples from the region of Ahmedabad with reference to habitats mentioned above. From some of these, collections were drawn at suitable regular intervals, the material was studied and separate accounts were and are planned to ultimately present a sumtotal picture of the diatom flora, elucidating features of interest, if any are found. Wheresoever it was possible, results of chemical analysis of water were availed and indicated with particular reference to salinity and $\mathrm{pH}$.

In compliance with the aspired plan indicated above, studies have been published relating to habitats no. 1 and $2 \mathrm{a}$. In this paper the diatom communities derived from habitats nos. $2 b$ and 3 are dealt with. The material here was collected from the compound of the Gujarat College at a monthly interval from July 1956 to December 1957 , this includes two rainy seasons. After this period the collection work got suspended on account of the author's transfer to a new place.

The material from garden reservoirs comprised of loose, granular, greenish, slimy masses of matter mixed with some species of Myxophyta, was collected in form of encrustations on inner walls of reservoirs and freely floating flakes of matter mostly derived from the same. This material represented only small forms of diatoms, among these Amphiprora paludosa W. SMITH v. subsalina CL., was predominant and was associated with Caloneis beccariana GRUN., Nitzschia microcephala GRUN. v. elegantula GRUN. and Surirella ovalis BRÉB. v. guttata $\AA$. BERG, which also occurred in good numbers.

The wet soil samples and others derived from ephemeral rainwater puddles mostly showed the preponderance of species of Nitzschia, Nitzschia amphibia GRUN., N. - v. acutiuscula GRUN., $N$. microcephala GRUN. and $N$. frustulum (KÜTZ.) GRUN. being more common and often associated with species of Achnanthes, whereas other forms were recorded as stray specimens. 
The salient feature of this study is that with the exception of Navicula cuspidata KüTz. v. ambigua (EHR.) CL., none of the diatoms showed more than $50 \mu$ size. Even in case of the said diatom there were only very stray specimens noted of more than $50 \mu$ length. In other words, the diatomflora was comprised of nannophytes and $N$. cuspidata v. ambigua, which was usually represented by much larger specimens (above $60 \mu$ ) elsewhere in Ahmedabad, was found here in conformity with the smaller life-forms by displaying nannism. Nothing could be done, due to several difficulties which confronted the author, to find out the causative factors or forces which prevented the formation of larger species of diatoms in these habitats. However, a fact could be recalled that in reservoirs there was ample contamination of rotting blackish green organic matter accumulated over years, high per centage of calcium carbonate and competing Myxophytes, besides water being disturbed fairly frequently. Whereas, in cases of samples derived from wet soils under garden taps and shortwhile rain-water puddles the soil factors must have been responsible as being pointed out by BRISTOL (1920), LUND (1945-46) and others, to promote the formation of small species of diatoms only. All the diatoms recorded from this locality were perennials with the exception of forms obtained from shallow ephemeral rain-water puddles. In the latter case, because of the collection work being discontinued with drying up of the soil. The frequency counts suggested only slight seasonal variations. Similar observations also were made of collections made from an identical garden reservoir at the $M$. N. College, Visnagar, during the year 1958 January to June 1959 when the author was attached to that college.

The source of water supply to the garden reservoirs happen to be a large garden well of which the data of water analysis is as follows for the year 1956-57:

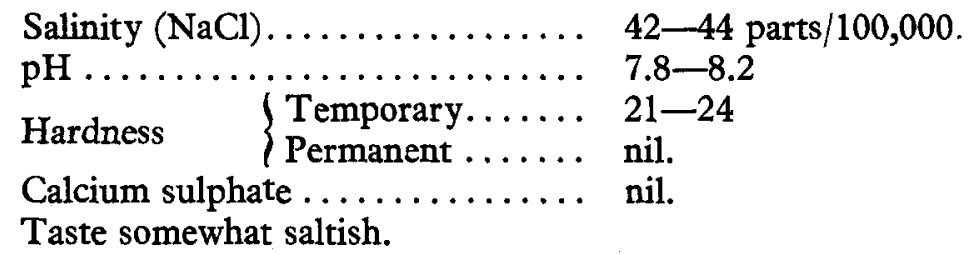

This data was obtained through the kind office of the Asstt. Officerin-Charge Public Health Laboratory, Municipal Corporation, Ahmedabad, to whom the author's thanks are due.

In this account the dimensions are given for all the species of diatoms recorded from this area but as usual descriptions and illustrations are avoided of all those recorded elsewhere in the Indian literature with a few exceptions. Under each diatom short notes also 
are given pertaining to their ecology, occurrence and distribution in the region of Ahmedabad. In case of Caloneis beccariana GRUN. and Amphiprora paludosa W. SM. v. subsalina $\mathrm{CL}$, some life-history features also are brought into relief which conform to statements presented by HustedT (1949—50) and CLEVE (1894-1895), respectively. The standard authentic works have been relied upon for the Halobion data.

\section{Systematic EnUmeration}

1. Cyclotella meneghiana KüTz. Diam. $10-17 \mu$ and striae $7-8$ in $10 \mu$.

This is a widely distributed species in whole of Ahmedabad but its gregarious formation was noted mainly in brackish waters (collections from Khari-cut canal). At other places it occurred in decaying masses of vegetable matter. In the present area it was recorded in good numbers in the encrustations but known to be stray in wet soil samples. Its place in the Halobion system . . . . . . . ....... Halophilous.

2. Achnanthes microcephala KüTz. Length $14-18 \mu$, breadth $2.8-3 \mu$ and striae $28-30$ in $10 \mu$.

This is also a widely distributed diatom in Ahmedabad. In certain reservoirs and road-side pools it was somewhat gregarious. However, in the present area it was fairly represented on the wet soils but was stray in reservoirs. Its place in the halobion system........... Halophobous.

3. Achnanthes pseudobiasolletiana sp. nov. (Figs. 1-5)

Valvae $8-14 \mu$ longae atque $2.8-3.5 \mu$ latae, late-lanceolatae, apicibus constrictis, productis ac late-rotundatis. Valva raphida: raphe tenuis et recta; area axialis angustissima; area centralis parva ac paululum elliptica; striae circiter 28 in $10 \mu$, tenues atque aliquamtum radiales. Valva sine raphide: pseudoraphe angusta, linearis; area centralis indistincta; striae circiter $26-27$ in $10 \mu$, aliquamtum radiales. Typus lectus a H. P. GANDHI ad cisterna in horto die $1956-57$, et positus in herbario proprio auctoris sub numero, slide AHM-GC. 5.

Valves $8-14 \mu$ long and $2.8-3.5 \mu$ broad, broadly lanceolate with constricted, produced broadly rounded ends. Valve with raphe: raphe thin and straight; axial area very narrow; central area small and very slightly elliptical; striae about 28 in $10 \mu$, fine and slightly radial. Valve without raphe: pseudoraphe narrow, linear; central area inevident; striae about $26-27$ in $10 \mu$ slightly, radial. 
This diatom although looks like $A$. biasolletiana (KüTz.) GRUN. (VAN HeurCK. 1896, Treat. Diat., 281, pl. 8, f. 331; HuSTEDT, 1930, Bacil., p. 199, f. 289; - 1930-37, Kieselalg., p. 379, f. 823; ClevEEuler, A., 1951-55, Diat. Schwed. Finn.-III, 42, f. 573 a-e), in the shape but differs in being much more slender i.e. breadth being 2.8-3.5 only in contrast to the minimum of $4 \mu$, recorded for the smallest form by HusTEDT and others. Moreover, the striae are slightly more in number besides they being distinctly radial on both the valves. It also differs from $A$. wolffi Foged (FoGED, N., 1957, Diat. Rennell Isl., p. 55, pl. 4, f. 16-17), in the similar details. It is hence considered to be a new species.

This species was collected from a couple of reservoirs growing in the encrustations and slimy depositions on dead floating leaves. It occurred in good numbers throughout the year. In the samples collected from the wet soils under the garden taps it occurred as a stray form. Elsewhere in the region of Ahmedabad it found no distribution except in some pools in the Sabermati river or similar garden reservoirs. Its place in the halobion system. . . . . . . ?

4. Achnanthes affinis Grun.: Length $15-17 \mu$, breadth $3 \mu$, striae on raphe valve 28 and raphe-less valve nearly 30 in $10 \mu$.

This species was found to be well distributed in Ahmedabad but it usually occurred in small numbers mixed with vegetable matter and slime. It also occurred on wet soils, pools, puddles and ditches formed during the rains. In the present locality, it was mostly collected from rain-water puddles and wet soils under the garden taps. However, it was significantly absent from the reservoirs? Its place in the halobion system............ Indifferent.

5. Achnanthes exigua GRUN.: Length $12-14 \mu$, breadth $4.2-4.5 \mu$ and striae 25 on the raphe valve and about 22 on rapheless valve in $10 \mu$.

This diatom was collected from a variety of wet situations in Ahmedabad, but more abundantly noted from fountain reservoirs, road-side ponds, pools and large ditches and from the clusters of living and dead vegetable matter collected on borders of large tanks and lakes. In the present area it was quite frequently collected from wet soils under garden taps and rain-water puddles but in the reservoir it occurred only sparsely. Its place in the halobion system .... .................... Indifferent.

6. Caloneis beccariana (GRUN.) CL. (Figs. 6-10)

Cleve, P. T., 1894-95, Synop. Nav. Diat. pt. I, p. 50, pt. II, pl. 1, f. 7; HustedT, 1949-1950, Diat. Sinai-Halbinsel, p. 44, f. 1-7; Foged, N., 1959, Diat. Afghanistan, 49, pl. 7, f. 6; GANDHI, 
1955, Diat. Partabgarh, p. 313, f. 11 (= C. clevei (LaGsT.) CL.). Valves $26-43 \mu$ long and $5.6-8.2 \mu$ broad, lanceolate to linearlanceolate, somewhat inflated in the middle with constricted, capitate to subcapitate broadly rounded ends. Raphe thin or coarse and conspicuous with unilaterally bent central pores and slightly curved terminal fissures. Axial area fairly wide, linear-lanceolate to lanceolate, rarely narrower; central area quite large and reaching the sides, sometimes more widened on one side than the other or narrowly reaching the sides, otherwise quite variable. Striae $21-22$ in $10 \mu$, but rarely upto 24 in $10 \mu$, particularly in some smaller forms, conspicuously radial, rarely less so in the middle but clearly convergent at the ends, crossed by a fine marginal line. The typical dimensions recorded for the type are as follows:

\begin{tabular}{llll} 
Length & \multicolumn{2}{l}{ Breadth } & Striae in $10 \mu$ \\
\hline $26 \mu$ & 6 & $\mu$ & 22 \\
$34.5 \mu$ & 7.6 & $\mu$ & $23-24$ \\
$35 \mu$ & 7.5 & $\mu$ & $21-22$ \\
$35 \mu$ & 7.6 & $\mu$ & 22 \\
$37 \mu$ & 7.5 & $\mu$ & $21-22$ \\
$38 \mu$ & 8.2 & $\mu$ & $21-22$ \\
$43 \mu$ & $7.5-8 \mu$ & $21-22$
\end{tabular}

This diato $m$ appears to be a very variable species both in the shape and structural details. With reference to the literature cited above, the shape varies from broadly lanceolate (CLEvE, HUSTEDT) to linearlanceolate (HUSTEDT, FOGED) with ends distinctly capitate to subcapitate (HUSTEDT, FOGED) even apparently only broadly produced and rounded (Hustedt, f. 6). Looking at the axial area, Cleve represents it to be uniformly narrow and linear, according to HuSTEDT it is narrowly lanceolate to broadly lanceolate as much as $1 / 3$ or more the width of the valve (much differently indicated than by Cleve) and FogED indicates it to be extremely narrow. Again, the central area seems to differ to a very large measure, from being very wide to narrowly reaching the sides, more widened on one side than the other (HUSTEDT), unilateral or not at all extended to the sides but only slightly formed (FOGED). The number of striae according to Husted and Cleve are 21 in $10 \mu$ but Foged counts them to be $21-22$ in $10 \mu$.

From the continuous examination of the material for over a period of a year all the variations indicated above were observed of which the present set of illustrations bear the testimony. However, the specimens illustrated by FOGED and HuSTEDT (cf. f. 4) were never observed. 
Also the maximal dimensions were never recorded which are: $27-70 \times 8-14 \mu$ and $26-75 \times 7 \mu$, according to HUSTEDT and CLEVE respectively. The number of striae usually recorded were $21-22$ but rarely counted upto 24 in $10 \mu$, slightly closer towards the apices.

Again, from the present study it was felt that $C$. hultenii B. PeTERSEN and C. clevei (LAGST.) CI. described by Hustedt (HustedT, 1930 , Bacil., p. 236, f. 359) probably lie within the cycle of $C$. beccariana (GRUN.) Cl. than the otherwise-but as boundry cases or remotely. Author's C. Clevei (GANDHI, 1955, Diat. Partabgarh, p. 313, f. 11) is also C. beccariana, as it could be ascertained with the availability of more and appropriate literature. Here, the author is grateful to Dr. B. J. ChOLNOKY for indirectly making a reference to this in one of his personal letters. VenKataraman's diagnosis of C. clevei (Venkataraman, 1956, S. I. Diat., p. 5, f. 10) appears to be unreliable in as much as that he gives in the text and illustration the course of striae to be radial throughout. He is, therefore, unreasonable in bringing reference of $C$. hultenii B. PET. While going through his paper under reference there may be found ample drawbacks which suggest that he bestowed little care in studying his material and the literature.

Further, from the continuous observations of the collection it was also felt that HUSTEDT's fig. 6 of C. beccariana be treated as a variety, since these smaller forms here not only showed broadly produced rounded ends but also somewhat denser striae, about $26-27$ in $10 \mu$, which is being effected in the following.

This species was collected from the garden reservoirs in abundance growing among other things in the slimy encrustations. Its period of maximum growth was in months of September and October 1956/57, but for the rest of the year it was seen in lesser numbers. This species does not seem to be well distributed in Ahmedabad since only $10 \%$ of samples were found to contain it usually in smaller number. These collections were from similar habitats. A couple of tubes from the Kankaria lake also represented it as a stray form. Its place in the halobion system. . . . . . . . . . . . . . . . . . . . ?

\section{Caloneis beccariana v. hustedtii v. nov. (Figs. 11-12)}

Valvae 13.2-22 $\mu$ longae atque 5-5.2 $\mu$ latae lineari-ellipticae vel subellipticae, apicibus constrictis, late-productis et rotundatis. Raphe tenuis et recta, poris centralibus aliquantum unilateraliter inclinatis atque fissuris terminalibus aliquantum curvatis. Area axialis angusta, sublanceolata; area centralis angusta, rectangularia ad margines perveniens. Striae circiter $26-27$ in $10 \mu$, paulum radiales atque in utroque apice paululum convergentes et lineam 
longitudinalibus ad margine interruptae. Typus lectus a H. P. GANDHI ad cisterna in horto die 1956-57, et positus in herbario proprio auctoris sub numero, slide AHM-GC. 6.

Valves 13.2-22 $\mu$ long and 5-5.2 $\mu$ broad, linear-elliptical to subelliptical with constricted, broadly produced rounded ends. Raphe thin and straight with central pores unilaterally bent and terminal fissures slightly curved. Axial area narrowly lanceolate; central area small, rectangular and reaching the sides. Striae about $26-27$ in $10 \mu$, slightly radial and towards the apices very slightly convergent, crossed by the longitudinal line near the margines.

This diatom differs from the above type in having clearly constricted broadly produced rounded ends. Moreover, the central area is small, rectangular and the striae are comparatively denser. It is therefore regarded as a new variety and named in honour of Dr. HuSTEDT of Bremen.

This diatom was found associated with C. beccariana (GRUN.) CL. in encrustations of reservoirs. It occurred usually in small number throught the period of investigation, but never seen from the wet soils. From other parts of Ahmedabad, it was sparingly seen but a couple of samples got from fountain reservoirs of Seth Sarabhai's garden contained it in small a number. Its place in the halobion system....................?

8. Caloneis bacillum (GRUN.) MeresCH. (Fig. 13): Length 14.2-18 $\mu$, breadth $5.6-6 \mu$ and striae $26-28$ in $10 \mu$.

This species was collected principally from garden reservoirs, fountains, in some road-side pools. Chandola and Kankaria lakes, usually mixed with living and dead vegetable matter. It was found to be fairly distributed in the region of Ahmedabad. In the present area it occurred in the reservoirs as well as on the wet soils under the garden taps. Stray specimens also were seen in rain-water puddles of longer duration. It appeared conspicuously in reservoirs during October and lasted thus till middle of November then it was stray. Its place in the halobion system $\ldots \ldots \ldots \ldots \ldots \ldots$. Indifferent.

9. Navicula cuspidata KÜTZ. v. ambigua (EHR.) CL. (Fig. 14) Length $38.2-69 \mu$, breadth $10.5-16 \mu$, transverse striae about 18 and longitudinal ones about 27 in $10 \mu$, longitudinal striae were found to be rather indistinct.

This diatom finds a very wide distribution in the region of Ahmedabad but was never known to occur in abundance. It was also obtained from moist soils occassionally with craticular plates. In the present area it occurred usually in smaller numbers both in the 
garden reservoirs and wet soils for the entire period of investigation. From the reservoirs very small specimens were collected of which probably no record exists in the literature. Its place in the Halobion system $\ldots \ldots \ldots \ldots \ldots \ldots \ldots \ldots$ Indifferent.

10. Navicula mutica KüTz. Length $12-18 \mu$, breadth $7-7.4 \mu$, striae about 18 in $10 \mu$.

This diatom was collected mostly from wet soils under the garden taps and rain-water puddles associated with different species of Nitzschia. In encrustations of reservoirs it was singularly absent. Elsewhere in Ahmedabad, it occurred usually in similar situations as also in the marginal slime of ponds, tanks and road-side pools. Stray specimens also were collected from Naginawadi pool around a leaking pipe. Its place in the Halobion system ...... Indifferent.

\section{Pinnularia macra sp. nov. (Figs. 15-16)}

Valvae $14-23 \mu$ longae atque 3-3.6 $\mu$ latae, parvae, lineares, marginibus parallelis vel leniter convexa, apicibus valde constrictis, late capitatis rotundatis. Raphe tenuis et recta, ornata poris centralibus unilateraliter inclinatis, fissuris terminalibus curvatis. Area axialis plus minus late-lanceolata; area centralis amplissima, rhomboidea usque ad margines perveniens. Striae 16-18 in $10 \mu$; crassae, radiales ac gradalim abbreviatae in medio atque in utroque apice convergentes. Typus lectus a $\mathrm{H}$. P. GANDHI ad solum humidus in horto die 1956-57, et positus in herbario proprio auctoris sub numero, slide AHM-GC. 8.

Valves $14-23 \mu$ long and 3-3.6 $\mu$ broad, small, linear, sides parallel to feebly convex, ends strongly constricted, broadly capitate and rounded. Raphe thin and straight with central pores unilaterally inclined and terminal fissures curved. Axial area more or less broadly lanceolate; central area quite large, rhomboid and extended to the sides. Striae 16-18 in $10 \mu$, coarse, radial and gradually abbreviated in the middle and convergent at the ends. The following is the table of typical dimensions recorded for this type

\begin{tabular}{lcc} 
Length & Breadth & Striae in $10 \mu$ \\
\hline $14 \mu$ & $3.3 \mu$ & 16 \\
$15.3 \mu$ & $3.1 \mu$ & 16 \\
$16 \mu$ & $3.3 \mu$ & $17-18$ \\
$23 \mu$ & $3.0 \mu$ & $16-18$ \\
$23 \mu$ & $3.6 \mu$ & 18
\end{tabular}


This species does not compare well with any of the following species

1. Pinnularia interrupta W. SM. f. minor B. Pet. (Petersen, 1928, Aërial Alg. Iceland, p. 405, f. 25) = P. biceps GREg. v. minor (B. Pet.) A. Cl. (Cleve-Euler, 1955, Diat. Schwed. Finn. -IV, p. 63, f. $1088 \mathrm{k}-\mathrm{n})$.

2. P. interrupta f. minutissima Hust. (Hustedt, 1930, Bacil., p. 317 , f. 574$)=P$. biceps v. gregorii A. CL. f. minutissima HUST. (Cieve-Euler, op. cit.s, p. 62, f. 1088 g).

3. P. kneuckerii Hust. (HustedT, 1949-50, Diat. Sinai Halbinsel, p. 50, f. 22-32; Foged, N., 1959, Diat. Afghanistan, 65, pl. 8, f. 4-5).

4. P. saxicola J. W. G. Lund (Lund, J. W. G., 1946, Soil Alg.-II, p. 88, f. 10 G-I; FoGED, N., op. cit., p. 65, pl. 8, f. 6)

and some others, although all these have smaller size and more or less a similar appearance. The present species, however, is distinguished from the rest in having much slender valves (the maximum breadth of which is only $3.6 \mu$ in contrast to others), very clearly capitate rounded ends, wide lanceolate axial area, enlarged rhomboid central area (also present in $P$. saxicola) and more important is the course of striae which are clearly radial and gradually abbreviated in the middle part unlike in P. saxicola which is also a soil diatom. Again, this species has some resemblance of $P$. interrupta f. minutissima Hust. of FoGEd (FoGEd, N., 1957, Diat. Rennell Isl., p. 72, pl. 7, f. 10) but the author remarks that,$\ldots \ldots$ has been referred here with some hesitation", after referring to HUSTEDT's type. Considering these remarks to be valuable, it is felt here to erect present specimens as a new species.

This species was fairly well represented in the collections from the college compound. It occurred more frequently in encrustations of reservoirs along with Caloneis beccariana (GRUN.) CL. and Amphiprora paludosa W. SM. v. subsalina CL. as well as in granular mass floating on the water surface. Some samples derived from wet soils under the garden taps also yielded it in smaller numbers. From other parts of Ahmedabad, it was only casually recorded and that too from similar situations. This species became more frequent in the reservoirs during late October. Its place in the Halobion system ....?

12. Amphiprora paludosa W. SM. v. subsalina CL. (Figs. 17-19) Cleve, P. T., 1894-95, Synop. Nav. Diat.,-I, p. 14; Hustedt, 1930, Bacil., p. 340; Cleve-Euler, A., 1952, Diat. Schwed. Finn.-V, 31 , f. $1400 \mathrm{~m}$.

Frustules $25.6-50 \mu$ long and $26-27 / 28-32 \mu$ broad at the broadest and at constriction $19-22 \mu$ broad, very weakly silicified 
hence delicate, somewhat obliquely or sigmoidly rectangular, deeply constricted in the middle with broadly rounded corners in the girdle view. Alae strongly undulate with deep rectangular but irregular recesses 1-2 (of junction line). Longitudinal bands in girdle zone fine, numerous, $12-15$ in $10 \mu$, slightly sigmoid. Striae $18-20$ in $10 \mu$, usually $22-24$ in $10 \mu$, fine but distinct and radial.

This diatom was found to be abundantly growing in mucilagenous matter encrusting the reservoirs or in free-floating masses detached from the same. In fresh-condition it appeared conspicuously with olive-green or pale chromatophores. It became more abundant during late September both in the reservoir and in a large tumbler kept under observation since August 1957, in a secluded corner of the laboratory. From the observations it appeared to be a very variable type corroborating the statement of CLEVE, ,A. paludosa is a very variable species, closely connected with $A$. alata KüTz. ..." Some of the specimens illustrated here perhaps bear the testimony to the same. From other parts of Ahmedabad, it has not been observed, perhaps it may be due to its very hyaline nature hence passed unnoticed. Its place in the Halobion system ........ Mesohalobous

13 Amphora veneta (KüTZ.): Length $14-20 \mu$, breadth $7-10 \mu$, striae $20-26$ in $10 \mu$

This diatom was mostly collected from wet soils under garden taps, on the border of ponds, pools, tanks and other similar situations. Stray specimens also were collected from the garden reservoirs occurring in encrustations. A fairly well distributed diatom in Ahmedabad. Its place in the Halobion system ....... Indifferent

\section{Amphora acutiuscula KüTz. (Figs 20-21)}

Cleve, P. T., 1895, Synop. Nav. Diat., pt. II, p. 121; CleveEuler, A., 1953, Diat. Schwed. Finn.-III, p. 98, f. 686 a-b; Hustedt, 1930, Bacil., p. 346 (= A. coffaeaformis AG. v. acutiuscula (Kütz.) Hust.).

Frustules $21-27 \mu$ long and 9-11 $\mu$ broad, linear-elliptical with constricted, broadly produced, truncate ends in girdle view. Longitudinal bands in the girdle view many and fine. Valve convex and somewhat straight in the middle part on the dorsal side and slightly concave on the ventral side; ends produced and narrowly capitate. Raphe thin, straight and close to the ventral side. Central area not clearly defined. Striae $16-18$ in $10 \mu$, radial and interrupted by longitudinal hyaline bands.

This diatom was collected from many parts of Ahmedabad in smaller or larger numbers. It was found sparingly in road-side pools, ditches and ponds, but more frequently in garden reservoirs and 
fountains. In the present area it occurred in encrustations of reserviors as well as on moist soils under garden taps and rain-water puddles, but in the latter case only as a stray specimen.

Its place in the Halobion system .......... Mesohalobous.

15. Hantzschia amphioxys (EHR.) GRUN. Length $22-38 \mu$, breadth $5-6$ rarely $7 \mu$, keel punctae $6-8$ in $10 \mu$, striae $16-20$ in $10 \mu$.

This diatom was collected mostly from rain-water pools, puddles or ditches mixed with fine slime and/or clusters of wet mosses on the garden brick-work. In the present area it was found in samples derived from wet soils under garden taps and rainwater puddles. A widely distributed diatom but occurring only in small numbers with the exception of some rainwater puddles. Its place in the Halobion system .......... Indifferent.

16. Nitzschia microcephala GRUN. Length $8-14 \mu$, breadth $2.8-3 \mu$, keel punctae about 13 in $10 \mu$, striae $30-32$ in $10 \mu$.

This is a widely distributed species in Ahmedabad, frequently found in pools, ponds, ditches specially in the marginal slime. In the present area it occurred in encrustations of reservoirs as well as on wet soils under garden taps and rain-water puddles. Its place in the Halobion system ......... Halophilous or Indifferent.

17. Nitzschia microcephala v. elegantula GRUN. (Fig. 22)

Van Heurck, 1896, Treat. Diat., p. 402, pl. 17, f. 559; CleveEuler, A., 1952, Diat. Schwed. Finn.-V, p. 88, f. 1499 e.

Valves $9.5-13 \mu$ long and $2.5-2.8 \mu$ broad, small, linear with slightly concave sides in the middle and constricted, distinctly produced capitate ends. Keel very excentric with small but distinct keel punctae $12-13$ in $10 \mu$. Striae about $26-30$ in $10 \mu$, rather fine.

This diatom appears like $N$. jugiformis Hust. (HusTEDT, 1922, Bacil. Innerasien, p. 149 , pl. 10, f. $60-61$ ) but differs in not having deeply constricted middle part. Moreover, the apices here are more abruptly narrowed therefore broadly cuneate, constricted produced and capitate. Keel punctae also are somewhat denser. Here the author wishes to express his grateful thanks to Dr. P. J. HaLICKI for supplying the photostat copy of this much needed reference.

This species was well represented in the region of Ahmedabad. It was collected from several garden reservoirs, fountains, storage tanks and on permanently wet soils under garden taps. It mostly occurred in association of some Myxophyta but sometimes also in slimy films on wet soils. In the present locality, it was available everywhere but more in number in encrustations of reservoirs. Its period of maximum growth was noted to be from November to December. Its place in the Halobion system ...........? 
18. Nitzschiaa mphibia GRUN. (fig. 23) Length $13-35 \mu$, breadth $3-4 \mu$, keel punctae 8-9 in $10 \mu$, striae about $17-18$ in $10 \mu$.

19. Nitzschia amphibia v. acutiuscula GRUN. Length $20-42.6 \mu$, breadth $3-5 \mu$, keel punctae $7-8$ in $10 \mu$ and striae 16 in $10 \mu$.

These two diatoms were found throughout the region of Ahmedabad, mostly occurring in the slimy matter lying on borders of wet situations. In samples derived from wet soils they were usually smaller in size. In certain ponds they were gregarious. In the present locality, they occurred both in the garden reservoirs and wet soils under taps and puddles. Their place in the Halobion system ...... ......................... Indifferent.

20. Nitzschia frustulum (KüTz.) GRUN.: Length $20-30 \mu$, breadth 3-4 $\mu$, keel punctae 9-11 in $10 \mu$, striae about 22 in $10 \mu$

This species was collected along with the above type but sometimes more commonly seen in certain pools, puddles and ditches on the road-side. In the present area it occurred mostly on wet soils, rainwater puddles and pools but only stray specimens were seen in samples from garden reservoirs. Its place in the Halobion system ... .................... Indifferent.

21. Nitzschia lancettula O. MüLL. (Fig. 24)

Schmidt, A.: 1874-1944, Atlas Diat., t. 348, f. 52-53; HustedT, 1949, Diat. Albert Nat. Park, p. 141, t. 13, f. 39-47.

Valves $15-18 \mu$ long and $4.7-5.5 \mu$ broad, broadly lanceolate with narrowed produced rounded ends. Keel very excentric with keel punctae 7-8 in $10 \mu$, small beaded and distinct. Striae $16-18$ in $10 \mu$, fine but distinctly punctate, punctae about $18-20$ in $10 \mu$.

This diatom occurred comparatively in smaller number of collections from Ahmedabad. Most of these collections were from garden reservoirs, fountains or some permanently wet soils. With the exception of 3-4 samples it was mostly recorded as a stray biotope. In the present locality it was found more abundantly in reservoirs than on wet soils. Its place in the Halobion system ............. ? Indifferent.

22. Nitzschia torta sp. nov. (Figs. 25-26)

Valvae 36-40 $\mu$ longae atque 3.3-3.8 $\mu$ latae, lineares, aliquantum arcuatae, apicibus constrictis, longe-cuneatis rostratis et rotundatis. Carina valde excentrica, punctis carinalibus $7-8$ in $10 \mu$, crassis atque distinctis, mediis duobus remotioribus. Striae 18 vel 20 in $10 \mu$, distincte punctatae. Typus lectus a H. P. GANDHI ad cisterna in horto die 1956-57, et positus in herbario proprio auctoris sub numero, slide AHM-GC. 19. 
Valves $36-40 \mu$ long and 3.3-3.8 $\mu$ broad, linear, slightly arcuate with ends constricted, long-cuneate, rostrate and rounded. Keel strongly excentric, keel punctae 7-8 in $10 \mu$, coarse and distinct, two of the middle one distantly set. Striae 18 to 20 in $10 \mu$, distinctly punctate.

This species does not agree with any of the known types hence it is considered to be a new species. The figure no. 26 depicts an anomalous form found with the type.

This diatom was represented only in a small number of collections from Ahmedabad. These collections were mostly made from garden reservoirs and fountains by scraping the encrustation. In all these samples it appeared as a stray diatom. From the present area it was well represented in the garden reservoirs as a delicate yet beautiful Hantzschia like form. Its place in the Halobion system ..........?

23. Surirella ovalis (BRÉB.) v. guttata A. BERG (Figs. 27-28)

Berg, A., 1945, Diat. Sophia-Expedition, p. 23, t. 8, f. 281. Valves 33.8-43.7 $\mu$ long and 22.6-26.6 $\mu$ broad, heteropolar, broadly ovate with rounded apex and comparatively narrower base distinctly constricted, produced and rounded. Axial area a very narrow pseudoraphe. Flap margin not developed, flap projections and windows absent. Costae $30-45$ in $100 \mu$, rib-like, not reaching the middle-line, radial but more so towards the ends, alternating with 3-5 clear striae. Striae about 18-19 in $10 \mu$, coarse and strongly radial towards the ends. In certain specimens striae seemed to show a longitudinal refractive band which appeared to shift with the change of focus.

This species was represented in a small number (about 25 specimens in all were counted) in encrustations of reservoirs associated with Caloneis beccariana (GRUN.) Cl. and Amphiprora paludosa W. SM. v. subsalina CL. Elsewhere in Ahmedabad it was not observed except in a few samples brought from fountain reservoirs of Seth Sarabhai's garden. In the latter case it was found associated with $S$. ovalis BRÉB. and some Dianoflagellates. Its place in the Halobion system .....................? 


\section{ECOLOGICAL CONSIDERATION ON DIATOMS FOUND IN THE GuJARAT COLLEGE COMPOUND}

In light of the existing Halobion data of these diatoms, the following Halobion spectrum could be represented, thus

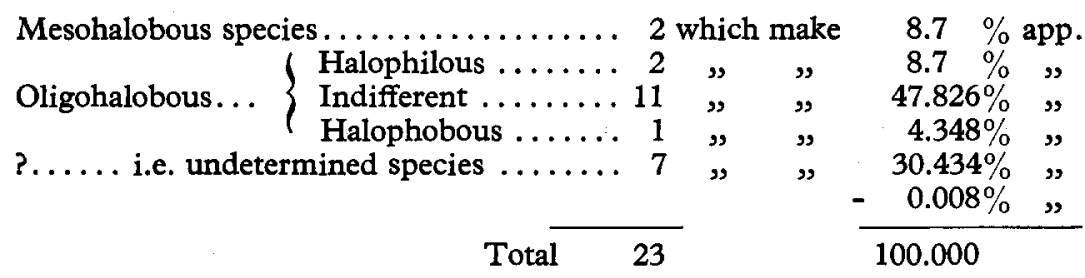

Likewise, the $\mathrm{pH}$-spectrum from the available records is the following:

Acidophilous . . . . . . . . . . . . . . . 0 which make $\quad 00.00 \%$ app.

Indifferent $\ldots \ldots \ldots \ldots \ldots \ldots \ldots \ldots \ldots \ldots \ldots, 2, \quad, \quad 8.70 \%$

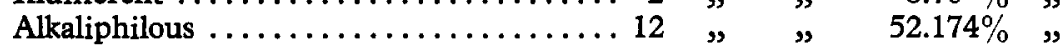

?. . i.e. undetermined species ......... 9 ", " $39.130 \%$ "

$$
\text { Total } 23 \quad \frac{100.000}{100}
$$

From the above Halobion spectrum it appears that a large number of salt loving diatoms exist in the present locality, especially in the garden reservoirs which means that the water is somewhat brackish. This fact seems to be corroborating with the results of chemical analysis of water available where the average range of salinity found to vary from 42 to 44 parts per 100,000 . With regards to the $\mathrm{pH}$ the water is markedly alkaline and therefore the Diatomflora is largely alkaliphilous with the exception of Achnanthes microcephala KüTZ. and Navicula mutica KüTZ. which are indifferent according to FOGED (1959). The remaining nine undetermined species with regard to $\mathrm{pH}$ may be considered as alkaliphilous on the basis of local data, until otherwise is proved.

Of the seven undetermined species of Diatoms of their Halobion character, the following consideration could be made:

Caloneis beccariana (GRUN.) C.., C. - v. hustedtii v. nov., Achnanthes pseudobiasolletiana sp. nov., Pinnularia macra sp. nov., Nitzschia microcephala GRUN. v. elegantula GRUN., and Surirella ovalis BRÉB. v. guttata $\AA$. BERG, may be recognised at least as halophilous species, since they occurred in abundance to good numbers in the water more or less of saline tendency. In the literature, Caloneis beccariana, Surirella ovalis (Euryhaline to Mesohalobous) and Nitzschia microcephala v. elegantula, are reported only from the 
brackish water and the last entity even from marine habitat. Again, Caloneis beccariana, was collected from highly polluted pools at Partabgarh (GANDHI, 1955) in which it occurred in encrustations on wet or partially submerged rocks. Moreover, all the above named entities were found here in close association of dominant species Amphiprora paludosa W. SM. v. subsalina CL. which has a marked Mesohalobous character. These observations, therefore, substantiate the present supposition-and indicate also the character of water in reservoirs. The constant presence of these Diatoms in good numbers here contemplates again that they belong to at least Halophilous if not Mesohalobous category, they being governed by the same ecological conditions as Amphiprora paludosa v. subsalina CL.

Regarding the one remaining Diatom, Nitzschia torta sp. nov., nothing could be said since the present data is rather meagre.

In the light of above consideration the Halobion spectrum becomes modified, thus:

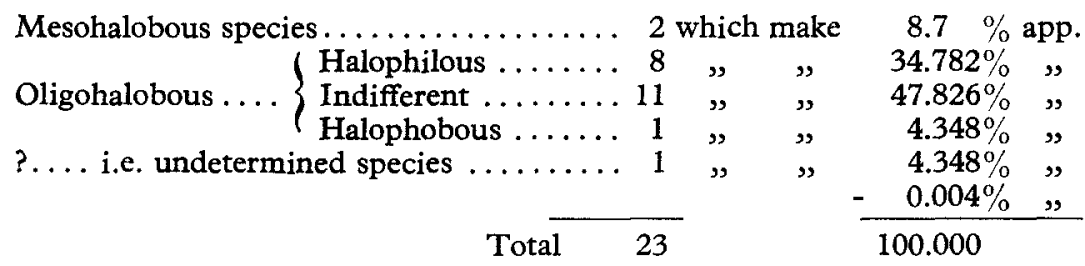

Further, concerning the diatom periodicity in the garden reservoirs nothing better could be said than that practically all the recorded species were permanent dwellers, and the seasonal fluctuation was represented only by a very small number of them as indicated in the text.

\section{SUMMARY}

While summarizing the results of the present investigation, the following could be stated:

that with the exception of two small notes by the author there exists little information of the Diatomflora of Ahmedabad region.

The diatoms of the present area are a special kind of biotopes characterised by small size. However, the causes leading to this nannism remain to be determined.

The observations regarding Caloneis beccariana (GRUN.) CL. and Amphiprora paludosa W. SM. v. subsalina CL., found to be in close harmony with those of HUSTEDT and CLEVE, respectively and further it is confirmed that they are very variable species.

The water of the present locality could be called somewhat 
brackish on the basis of a large number of salt-loving diatoms being found here. Moreover, they are all alkaliphilous even the new entities with the exception of two which are known to be indifferent for the $\mathrm{pH}$.

In light of the existing Halobion data and local observations some of the new entities and a few others are assigned their Halobion status. The spectrum relating to the same is also given.

The distribution of these diatoms is indicated for the region of Ahmedabad.

With regard to their periodicity recorded for over a year it was observed that almost all the species were perennials and a few among them showed slight rises any time from September to December.

Lastly, in all twenty-three diatoms are recorded from the present area representing ten genera. Of these, six are new records for India and three species and one variety is considered to be new.

\section{REFERENCES}

BERG, §. - 1945 - Diatomeen von der Sophia-Expedition im Jahre 1883, Ark. Bot., 32 A (1): 1-34.

BRISToL, B. M. - 1920 - On the Algal flora of some desiccated English soils, Ann. Bot. London, 34: 35-80.

Cleve-Euler, A. - 1951-5 - Die Diatomeen von Schweden und Finnland, I, V, II-IV, K. Sv. V. A. Handl., Fjärde Ser., 2 (1): 1-163; 3 (3): $1-153 ; 4(1)$ : $1-158 ; 4(5): 1-255 ; 5(4): 1-232$.

Cleve, P. T. - 1894-95 - Synopsis of the Naviculoid Diatoms, K. Sv. V. $A$. Handl., pt. I-II, 26 (2): 1-194; 27 (3): 1-220.

FoGED, N. - 1953 - Diatoms from West Greenland, collected by Tyge W. Böcher, Medd. am Gronland, 147 (10): 1-86.

- 1955 - Diatoms from Pearyland, North Greenland, collected by Kjeld Holman, ibid., 128 (7): 1-90.

- 1957 1. Diatoms from Rennell Island, Natur. Hist. Rennell Isl., Brit. Sol. Isl., 3: 1-117.

$-1959 \mathrm{a}$ - The Diatoms in the basalt area and adjoining areas of Archean Rock in West Greenland, Medd. om Gronland, 156 (4): 1-146.

- 1959b - Diatoms from Afghanistan, Biol. Skr. Den. Vid. Selsk., 11 (1): $1-95$.

GANDHI, H. P. - 1955 - A contribution to our knowledge of the fresh-water Diatoms of Partabgarh Rajasthan, $\mathcal{F}$. Indian bot. Soc., 34: 307-338. - 1959 - Notes on the Diatomaceae from Ahmedabad and its environsII. On the Diatomflora of fountain reservoirs of the Victoria Gardens, Hydrobiologia, 14 (2): 130-146.

- 1960 - On the Diatomflora of some ponds around Vasna village near Ahmedabad, F. Indian bot. Soc., 39: (in press).

GeitleR, L. - 1932 - Der Formwechsel der penneten Diatomeen (Kieselalgen) Arch. Protistenk., 78: 1-226.

Hustedt, F. - 1922 - Bacillariales aus Innerasien gesammelt von Dr. Sven Hedin, in Sven Hedin: Southern Tibet 1906-8, 6: 130-146.

- 1930 - Bacillariophyta (Diatomeae) in A. Pascher's Die SüsswasserFlora Mitteleuropas, H. 10, Jena. 
- 1930-37 - Die Kieselalgen Deutschlands, Österreichs und der Schweiz etc., pt. I-II, in Dr. L. Rabenhorst's Kryptogamen-Flora, H. 7, Leipzig.

- 1938 - Systematische und ökologische Untersuchungen über die Diatomeen-Flora von Java, Bali und Sumatra nach dem Material der Deutschen Limnologischen Sunda-Expedition, Arch. Hydrobiol. suppl., 15: 131-177, 187-295, 393-506, 638-790.

- 1949 - Süsswasser-Diatomeen aus dem Albert-National Park in Belgisch-Kongo, Expl. Parc Nat. Albert Miss. H. Damas 1935-36, 8: $1-199$.

- - 1949-50 - Diatomeen von der Sinai-Halbinsel und aus dem Libanon -Gebiet, Hydrobiologia, 2: 24-55.

Iyengar, M. O. P. \& Venkataraman, G. - 1951 - The ecology and seasonal succession of the Algal flora of the river Cooum at Madras with special reference to the Diatomaceae, $\mathcal{F}$. Madras Univ., 21: 140-192.

Lund, J. W. G. - 1945-6 - Observation on soil Algae-I. The ecology, size and taxonomy of British soil Diatoms, pt. I-II, New Phytol., 44 (2): 196-219; $45(1): 56-110$.

Petersen, J. B. - 1928 - The Aërial Algae of Iceland, Bot. Iceland, 2 (II): $225-447$.

- 1943 - Some Halobion spectra (Diatoms), Det. Kgl. Dansk Videns Sels. Biol. Meddl., 17 (9) :1-95.

___ -1946 - Algae collected by Eric Hulten on the Swedish Kamatchatka Expedition 1920-22, especially from hot springs, ibid., 20 (1): 1-122.

ReImer, C. W. - 1954 - Re-evalution of the Diatom species Nitzschia frustulum (Kütz.) Grun., Butler Univ. Bot. Studies, 11: 178-191.

Schmidt, A. - 1874-1944 - Atlas der Diatomaceen-Kunde, Taf. 1-460, Leipzig.

VAN HeURCK, H. - 1896 - A Treatise on the Diatomaceae (trans. by W. E. Baxter), London.

N.B.: The following ,ERRATA" appear to be necessary in HYDROBIOLOGIA Vol. XIV, no. 2, 15.12.1959, and the author is sorry that through oversight they remained so long.

\begin{tabular}{|c|c|c|c|}
\hline Page & Line & For & Read \\
\hline \multirow[t]{2}{*}{111} & 36 & „cum lineis aeque distantibus" & parallelis \\
\hline & 39 & „proximis" & proxime positis \\
\hline 114 & 1 & „lineare” & lineari \\
\hline 116 & 10 & "cum lineis aeque distantibus" & parallelis \\
\hline 133 & 27 & ,(Figs. 3-8, 18)" & (Figs. $3-8,19$ ) \\
\hline 135 & 23 & „(Figs. $11-20,20) "$ & (Figs. 11-12, 20) \\
\hline 136 & 1 & ,s," & is, \\
\hline 138 & 35 & ,(Fig. 14)" & (Fig. 13) \\
\hline \multirow[t]{2}{*}{139} & 19 & „(Fig. 15)" & (Fig. 14) \\
\hline & 35 & „(Fig. 16)" & (Fig. 15) \\
\hline \multirow[t]{2}{*}{140} & 6 & „(Fig. 17)" & (Fig. 16) \\
\hline & 19 & ,Fig. 18)" & (Fig. 17) \\
\hline
\end{tabular}




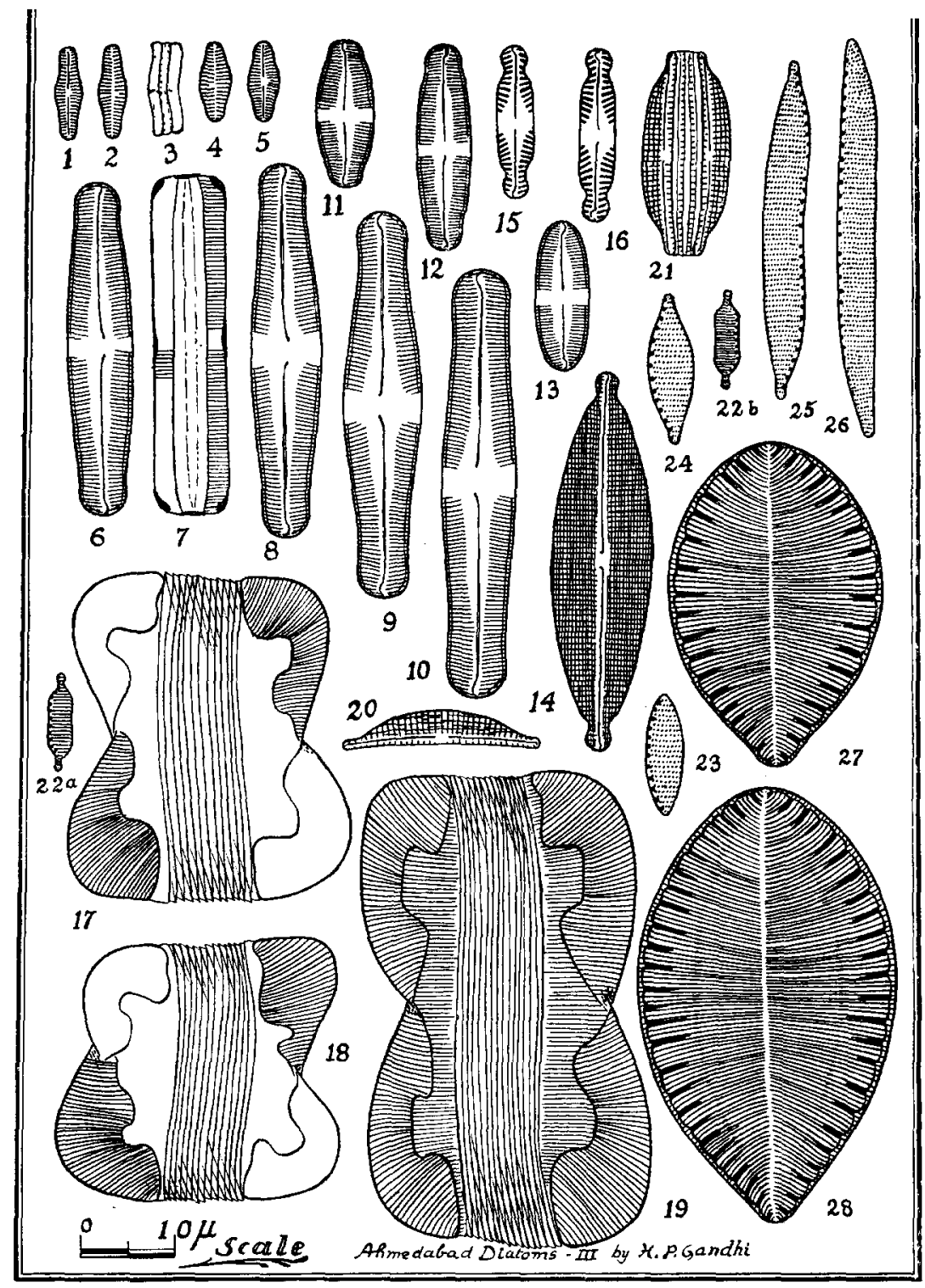

PLATE I

Fig. 1-5. Achnanthes pseudobiasolletiana sp. nov.

Fig. 6-10. Caloneis beccariana (GRUN.) CL.

Fig. 11-12. C. - v. hustedtii v. nov.

Fig. 13. C. bacillum (GRUN.) MERESCH.

Fig. 14. Navicula cuspidata KüTz. v. ambigua (EHR.) CI.

Fig. 15-16. Pinnularia macra sp. nov.

Fig. 17-19. Amphiprora paludosa W. SM. v. subsalina CL.

Fig. 20-21. Amphora acutiuscula KüTZ.

Fig. 22. Nitzschia microcephala GRUN. v. elegantula GRUN.

Fig. 23. N. amphibia GRUN.

Fig. 24. N. lancettula $\mathrm{O}$. MüLL.

Fig. 25-26. N. torta sp. nov. (no. 26 is an anomalous specimen)

Fig. 27-28. Surirella ovalis BREB. v. guttata $\AA$ BERG 